\title{
Cardiovascular risk factors and body fat distribution in brazilians aged 80 years or over
}

\author{
Fatores de risco cardiovascular e distribuição de gordura corporal em \\ brasileiros com 80 anos ou mais
}

Igor C. Gomes ${ }^{1}$, Vanessa R. dos Santos², Diego G.D. Christofaro³, Rômulo A. Fernandes ${ }^{3}$, Denise R. Bueno ${ }^{3}$, Ismael $\mathrm{F}$ Freitas Júnior ${ }^{3}$

\begin{abstract}
Study design: Cross-sectional study. Objective: To analyze the presence of cardiovascular risk factors (CRFs) according to the pattern of body fat distribution, in Brazilians aged 80 years or over. Methods: The sample consisted of 113 subjects, of 83.4 years, of both sexes. The percentages of total and abdominal body fat, hypertension and lipid profile were used for characterization of CRFs. The chisquare test was used to assess proportions of CRFs and the Mann-Whitney test was used to compare the results of adiposity. Results: Eutrophic subjects presented lower triglycerides $(p=0.017)$, total cholesterol $(p=0.001)$ and prevalence of both hypertension $(p=0.003)$ and hypertriglyceridemia $(p=0.007)$. Subjects with higher abdominal adiposity presented higher total cholesterol $(p=0.026)$ and prevalence of hypertriglyceridemia $(p=0.011)$ and hypercholesterolemia $(p=0.026)$ than those with no excess abdominal adiposity. Those with excess fat (total, abdominal or both), with the exception of glucose $(p=0.877)$, presented a high prevalence of CRFs. Those with both types of excess fat presented differences, with a higher prevalence level when compared to those with only one or neither of the excesses. Conclusion: Obesity, whether abdominal or total, is similarly associated with CRFs in subjects aged 80 years and over.
\end{abstract}

Key Word: Elderly. Epidemiology. Obesity. Cardiovascular Diseases.

\begin{abstract}
RESUMO
Modelo do estudo: Estudo transversal. Objetivo: Analisar a presença de fatores de risco cardiovascular (FRC) de acordo com o padrão de distribuição de gordura corporal em brasileiros com 80 anos ou mais. Materiais e Método: A amostra foi composta de 113 idosos, com média de idade de 83,4 anos, de ambos os sexos. O percentual de gordura corporal total e abdominal, hipertensão e perfil lipídico foram usados para caracterização dos FRC. O teste qui-quadrado foi utilizado para avaliação das proporções de FRC e o teste Mann-Whitney foi utilizado para comparar os resultados de adiposidade.
\end{abstract}

1. Doctor. Professor of the Department of Physical Education, University Maurício of Nassau, Natal, Brazil.

2. Doctoral student in Science of Kinetics Physical Education, State University Paulista "Júlio Mesquita Filho", Rio Claro, São Paulo, Brazil.

3. Doctor. Professor of the Department of Physical Education, State University Paulista "Júlio Mesquita Filho". Presidente Prudente, São Paulo, Brazil.
Correspondencia Faculdade Maurício de Nassau. Departamento de Educação Física. Av. Engenheiro Roberto Freire, 1514 - Capim Macio CEP: 59082-095 - Natal - RN / Brasil

Recebido em 07/04/2014 Aprovado em 09/06/2015 
Resultados: Idosos eutróficos apresentaram baixo triglicerídeos $(p=0,017)$ e colesterol total $(p=0,001)$ além de menores prevalências de hipertensão $(p=0,003)$ e hipertrigliceridemia $(p=0,007)$. Idosos com maior adiposidade abdominal apresentaram maior colesterol total $(p=0,026)$ e prevalência de hipertrigliceridemia $(p=0,011)$ e hipercolesterolemia $(p=0,026)$ quando comparados com os de menor adiposidade abdominal. Aqueles com excesso de gordura (total, ou abdominal ou ambos), com exceção da glicemia $(p=0,877)$, apresentaram alta prevalência de FRC. Aqueles com ambos os excessos de gordura apresentam diferenças, com maior nível de prevalência quando comparados aqueles com apenas um ou nenhum dos excessos. Conclusão: A obesidade, sendo abdominal ou total, é associada, da mesma maneira, com FRC em sujeitos com 80 anos ou mais.

Palavras-chave: Idoso. Epidemiologia. Obesidade. Doenças Cardiovasculares.

\section{Introduction}

Brazilian demographics show that average age and life expectancy of the population are increasing, and birth rates and infant mortality are decreasing. ${ }^{1}$

While in 2000 , subjects aged 80 or over accounted for only $17 \%$ of the total elderly population ( $\geq 65$ years), it is projected that, in 2050 , these individuals will represent about $28 \%$ of the population. ${ }^{1}$

The increase in life expectancy observed in the last decades has been accompanied by a burden of chronic non-communicable diseases, such as diabetes type II, hypertension, dyslipidemia2,3 and excessive accumulation of body fat ${ }^{4}$, especially sarcopenic obesity. ${ }^{5}$ These conditions, either alone or combined, increase cardiovascular risk factors (CRFs).

Evidence highlights that adipose tissue has a role in the development of a systemic inflammatory state. ${ }^{6}$ The adipocytes secrete a large variety of cytokines, which are related to insulin resistance, atherosclerotic plaque formation and cardiovascular disease. ${ }^{7}$

The visceral adiposity tissue (VAT) adipocytes are more metabolically active, more sensitive to lipolysis and more insulin-resistant than subcutaneous adiposity tissue (SAT) adipocytes. ${ }^{8}$

The interaction between excess body fat (total and abdominal) and increased cardiovascular risk is well established in all age groups. 3,9 However, there are few studies that analyze the pattern of body fat distribution and its association with CRFs in a population with more advanced age. Thus, the objective of this study was to analyze the presence of cardiovascular risk factors according to the pattern of body fat distribution, in Brazilians aged 80 years or over.

\section{Methods}

\section{Study Design}

Individuals aged 80 years and over were invited to participate in a pilot study of the SABE Study (Health, Well- being and Aging) conducted from October 2009 to May 2010 in the city of Presidente Prudente, São Paulo State, Brazil. The SABE Study, a multicenter, epidemiological and household based study coordinated by the Pan American Health Organization (PAHO), was performed in seven Latin American centers in 2000. In Brazil, the study was conducted in São Paulo City, and coordinated by the School of Public Health (FSP) at the University of São Paulo (USP), supported by PAHO and funded by the Foundation for Research Support of São Paulo (FAPESP) and the Ministry of Health (MS). All procedures relating to the sampling process, data collection, and database design have been published previously. ${ }^{10}$

\section{Subjects}

Individuals invited to participate in this study were informed about the objectives and methodology of data collection, and signed a "Statement of Informed Consent". All protocols were reviewed and approved by the Ethics Committee in Research of the São Paulo State University (Process no. 26/ 2009). Out of a total of 2,100 people aged 80 years and over living in the city of Presidente Prudente, 113 community-dwelling individuals with no limb amputations or mobility impairment were included in the study sample. 


\section{Anthropometry}

Body weight was measured with an electronic scale (precision $0.1 \mathrm{~kg}$ ) (Filizzola PL 150, Filizzola Ltda) and height with a wall-mounted stadiometer (precision $0.1 \mathrm{~cm}$ ) (Sanny®, São Paulo, Brazil). Both measurements were performed with the subjects barefoot and wearing light clothing. Body mass index (BMI) was calculated from the values of weight divided by height squared $\left(\mathrm{kg} / \mathrm{m}^{2}\right)$.

All anthropometric measurements were performed by the same researcher, according to standardized techniques. ${ }^{11}$

\section{Body Composition}

Body composition was estimated using a Dualenergy X-ray absorptiometry (DXA) scanner (Lunar DPX-NT; General Electric Healthcare, Little Chalfont, Buckinghamshire), with software version 4.7. The method estimated the body composition by fractionating the body into three anatomical compartments: fat-free mass (FFM), fat mass (FM) and bone mineral content. The assessment lasted for approximately 15 minutes, and the subjects remained immobile in a supine position throughout the scan, wearing light clothing while lying flat on their back with arms by their sides. The results were expressed in kilograms of FFM and FM, and in percentage of body fat (\%BF), and were transmitted to a connected computer for further analysis, according to the manufacturer's instructions. The DXA also enabled the assessment of trunk fat mass (TFM) in kilograms and percentage of trunk fat (\%TF). All data were collected by trained staff as described by Lohman et al. ${ }^{11}$

All DXA measurements were performed at the laboratory of the University, in a room with controlled temperature. Each morning before beginning the measurements, the DXA equipment was calibrated by the same researcher, according to the references provided by the manufacturer.

From the results of \%BF obtained, the subjects were classified as eutrophic or having excess total body fat, according to Morrow et al ${ }^{12}$, with percentages above $25 \%$ and $33 \%$ for men and women respectively. Regarding the \%TF, as there is no reference for abdominal adiposity in older people, the subjects were classified as having excess abdominal fat or normal abdominal fat according to the highest tertile, with percentages above $44 \%$ and $45 \%$ for men and women respectively.

\section{Blood Pressure and Self-reported hypertension}

An Omron HEM-742 digital meter, previously validated for use in adults, was used to measure systolic (SBP) and diastolic blood pressure (DBP). ${ }^{13}$ This variable was measured twice, on the right arm, with the elderly participant sitting down. The first measurement was taken after a minimum of 5 minutes rest, and the second measurement was taken two minutes after the first. ${ }^{14}$ The mean of these two measurements was used for analysis.

For the categorization of individuals as hypertensive or normotensive, a single question was asked: Has a doctor or nurse ever told you that you have high blood pressure?

If not, the use of antihypertensive medication was verified as a diagnostic criterion for hypertension. ${ }^{15}$

\section{Blood Sample Analysis}

Blood collection was performed, after a 12hour fasting, in a private laboratory located in the city of Presidente Prudente, Brazil. Samples were collected in vacuum tubes containing gel with an anticoagulant; after collection, blood was centrifuged for 10 minutes at 3,000 rpm. Total cholesterol (TC), high-density lipoprotein cholesterol (HDL-C), low-density lipoprotein cholesterol (LDLC) and very low-density lipoprotein cholesterol (VLDL-C), triglycerides (TG), and fasting blood glucose (BG), were assayed using an enzymatic colorimetric kit processed in an Autohumalyzer A5. ${ }^{16}$ The reference values adopted for characterization of hyperglycemia, hypertriglyceridemia and hypercholesterolemia were $\geq 100 \mathrm{mg} / \mathrm{dl} \geq 150 \mathrm{mg} / \mathrm{dl}$ and $\geq 200 \mathrm{mg} / \mathrm{dl}$, respectively. ${ }^{17}$

For this study four studied variables (hyperglycemia, hypertriglyceridemia, hypercholesterolemia and self-reported hypertension) were considered CRFs.

\section{Statistical Analysis}

The Kolmogorov-Smirnov test was used to verify the normality of the numerical data, and where the data did not present normal distribution, the nonparametric analysis was applied. 
The quantitative variables were presented as median and interquartile values. These variables were distributed and the Mann-Whitney test used to compare according to sex, \%BF and \%TF (controlled for sex and age) between the groups.

For each CRF, the frequency of participants who presented values above the respective recommendations was calculated. The frequency of individuals who had more than one CRF was also recorded. The chi-square test was used to test the proportions between those with the presence or absence of CRFs and each of the four major combinations of CRFs. Statistical analysis was performed using SPSS (SPSS inc. Chicago. IL), version 17.0, and the $p$ value was set at $5 \%$.

\section{Results}

Table 1 presents data on the median and interquartile interval of the general characteristics and CRFs of the sample, stratified by sex. No statistical differences were found in age, BMI, SBP, DBP, trunk fat (\%), TG and BG. Men had higher values of weight and height $(p<0.001)$ and women had higher TC levels $(p=0.001)$ and body fat $(\%)(p<0.001)$.

Table 2 demonstrates that the group with excess total body fat presented significantly higher TG $(p=0.017)$, TC $(p=0.001)$, and a higher prevalence of hypertension $(p=0.003)$. It is important to point out that the prevalence of hypertriglyceridemia was four times higher in the elderly who presented excess weight $(p=0.007)$.

Table 3 demonstrates that the participants with excess abdominal fat presented significantly higher values of TC $(p=0.026)$, and also significantly higher prevalences of hypertriglyceridemia $(p=0.011)$ and hypercholesterolemia $(p=0.026)$.

Alterations in the risk factors according to the absence or presence of excessive abdominal or total body fat, as well as the aggregation of these two outcomes, are presented in Figure 1. When comparing subjects without excess body fat (total and abdominal), those with the presence of one or both outcomes, with the exception of glucose $(p=0.877)$, presented higher prevalence of CRFs. The variables total cholesterol, triglycerides and having three or more of the analyzed cardiovascular risk factors (hypertension, total cholesterol, glucose and triglycerides) showed differences, with the highest prevalence in those individuals who presented both types of excess fat (total and abdominal) compared to those with only one or who did not present excess fat.

Table 1: Anthropometric, metabolic and hemodynamic characteristics of subjects aged 80 or over (Presidente Prudente, Brazil. 2010)

\begin{tabular}{|c|c|c|c|}
\hline Variables & $\begin{array}{r}\text { Male }(n=41) \\
\text { Median }\left(P^{25}-P^{75}\right)\end{array}$ & $\begin{array}{r}\text { Female }(n=72) \\
\text { Median }\left(P^{25}-P^{75}\right)\end{array}$ & p* \\
\hline Age (years) & $82.9(81.5-84.3)$ & $82.7(81.1-84.8)$ & 0.840 \\
\hline Weight (Kg) & $71.1(63.3-84.2)$ & $57.5(49.8-66.8)$ & 0.001 \\
\hline Height $(\mathrm{cm})$ & $164.5(159.8-169.3)$ & $150.6(145.8-155.0)$ & 0.001 \\
\hline BMI $\left(\mathrm{kg} / \mathrm{m}^{2}\right)$ & $26.2(23.6-30.5)$ & $25.9(22.8-28.7)$ & 0.327 \\
\hline $\mathrm{SBP}(\mathrm{mmHg})$ & $152.0(140.0-168.5)$ & $154.5(138.0-170.5)$ & 0.693 \\
\hline $\mathrm{DBP}(\mathrm{mmHg})$ & $78.0(70.0-86.0)$ & $74(68.2-87.7)$ & 0.623 \\
\hline Trunk Fat (\%) & $39.5(30.8-44.9)$ & $42.5(34.6-47.9)$ & 0.178 \\
\hline Body Fat (\%) & $32.7(25.6-35.7)$ & $42.2(35.0-48.2)$ & 0.001 \\
\hline TG $(\mathrm{mg} / \mathrm{dl})$ & $106.0(80.7-151.5)$ & $113.0(89.0-171.0)$ & 0.422 \\
\hline TC (mg/dl) & $182.5(155.2-203.0)$ & $211.0(189.0-230.0)$ & 0.001 \\
\hline BG (mg/dl) & $93.0(86.0-112.7)$ & $93.0(86.0-97.7)$ & 0.686 \\
\hline
\end{tabular}

$\left(^{*}\right)$ Mann-Whitney test; $\mathrm{P}^{75}$ - $75^{\text {th }}$ percentile; $\mathrm{P}^{25}$ - 25th percentile; BMI - Body mass index; SBP - Systolic blood pressure; DBP - Diastolic blood pressure; TG - Triglycerides; TC - Total Cholesterol; BG - Blood Glucose. 
Table 2: Comparison between subjects aged 80 years or over, with normal or excess total body fat.

\begin{tabular}{|c|c|c|c|}
\hline \multirow[b]{4}{*}{ Variables } & \multicolumn{2}{|c|}{ Total body fat } & \multirow[b]{4}{*}{$\boldsymbol{p}$} \\
\hline & \multirow{3}{*}{$\begin{array}{r}\text { Normal }(n=24) \\
83.1(3.6 \text { years) } \\
\text { Median (P25-P75) }\end{array}$} & \multirow{2}{*}{$\begin{array}{r}\text { Excess }(n=89) \\
83.3(2.5 \text { years })\end{array}$} & \\
\hline & & & \\
\hline & & Median (P25-P75) & \\
\hline \multicolumn{4}{|l|}{ Numerical* } \\
\hline $\mathrm{SBP}(\mathrm{mmHg})$ & $151.5(137.0-170.2)$ & $155.0(140.0-169.0)$ & 0.706 \\
\hline $\mathrm{DBP}(\mathrm{mmHg})$ & $71.5(64.5-93.2)$ & $77.0(70.0-86.0)$ & 0.478 \\
\hline TG (mg/dl) & $88.5(73.2-111.2)$ & $115.0(98.0-180.5)$ & 0.017 \\
\hline TC (mg/dl) & $194.5(159.7-216.0)$ & $202.0(179.0-227.0)$ & 0.001 \\
\hline $\mathrm{BG}(\mathrm{mg} / \mathrm{dl})$ & $87.0(80.5-94.7)$ & $94.0(86.0-106.5)$ & 0.273 \\
\hline \multicolumn{4}{|l|}{ Categorical $(\%) * *$} \\
\hline Hypertension & $41.6 \%$ & $74.1 \%$ & 0.003 \\
\hline HTG ( $\geq 150 \mathrm{mg} / \mathrm{dl})$ & $8.3 \%$ & $37.0 \%$ & 0.007 \\
\hline $\mathrm{HC}(\geq 200 \mathrm{mg} / \mathrm{dl})$ & $41.6 \%$ & $53.9 \%$ & 0.286 \\
\hline $\mathrm{HG}(\geq 100 \mathrm{mg} / \mathrm{dl})$ & $20.8 \%$ & $31.2 \%$ & 0.310 \\
\hline
\end{tabular}

$\left(^{*}\right)$ Mann-Whitney test Controlled for age and sex; $\left(^{* *}\right)$ Chi-square test; SBP - Systolic blood pressure; DBP - Diastolic blood pressure;

TG - Triglycerides; TC - Total Cholesterol; BG - Blood Glucose; HTG - Hypertriglyceridemia; HC - Hypercholesterolemia, HG - Hyperglycemia.

Table 3: Comparison between subjects aged 80 years or over, with normal or excess abdominal fat.

\begin{tabular}{|c|c|c|c|}
\hline \multirow[b]{4}{*}{ Variables } & \multicolumn{2}{|c|}{ Abdominal fat } & \multirow[b]{4}{*}{$p$} \\
\hline & \multirow{2}{*}{$\begin{array}{l}\text { Normal }(n=77) \\
83.5(3.0 \text { years })\end{array}$} & Excess $(n=36)$ & \\
\hline & & 82.7 (2.2 years) & \\
\hline & Median (P75-P25) & Median (P75-P25) & \\
\hline \multicolumn{4}{|l|}{ Numerical* } \\
\hline $\mathrm{SBP}(\mathrm{mmHg})$ & $155.5(140.0-170.2)$ & $149.0(135.0-164.0)$ & 0.412 \\
\hline $\mathrm{DBP}(\mathrm{mmHg})$ & $76.0(69.7-86.0)$ & $78.0(68.0-88.0)$ & 0.738 \\
\hline TG (mg/dl) & $103.0(81.0-147.5)$ & $138.0(98.7-197.5)$ & 0.921 \\
\hline TC (mg/dl) & $193.0(166.0-221.0)$ & $207.5(192.5-229.0)$ & 0.026 \\
\hline $\mathrm{BG}(\mathrm{mg} / \mathrm{dl})$ & $92.0(85.0-106.0)$ & $93.5(86.0-99.0)$ & 0.066 \\
\hline \multicolumn{4}{|l|}{ Categorical (\%)** } \\
\hline Hypertension & $66.2 \%$ & $69.4 \%$ & 0.735 \\
\hline HTG ( $\geq 150 \mathrm{mg} / \mathrm{dl})$ & $23.3 \%$ & $47.2 \%$ & 0.011 \\
\hline $\mathrm{HC}(\geq 200 \mathrm{mg} / \mathrm{dl})$ & $44.1 \%$ & $66.6 \%$ & 0.026 \\
\hline $\mathrm{HG}(\geq 100 \mathrm{mg} / \mathrm{dl})$ & $32.4 \%$ & $22.2 \%$ & 0.264 \\
\hline
\end{tabular}




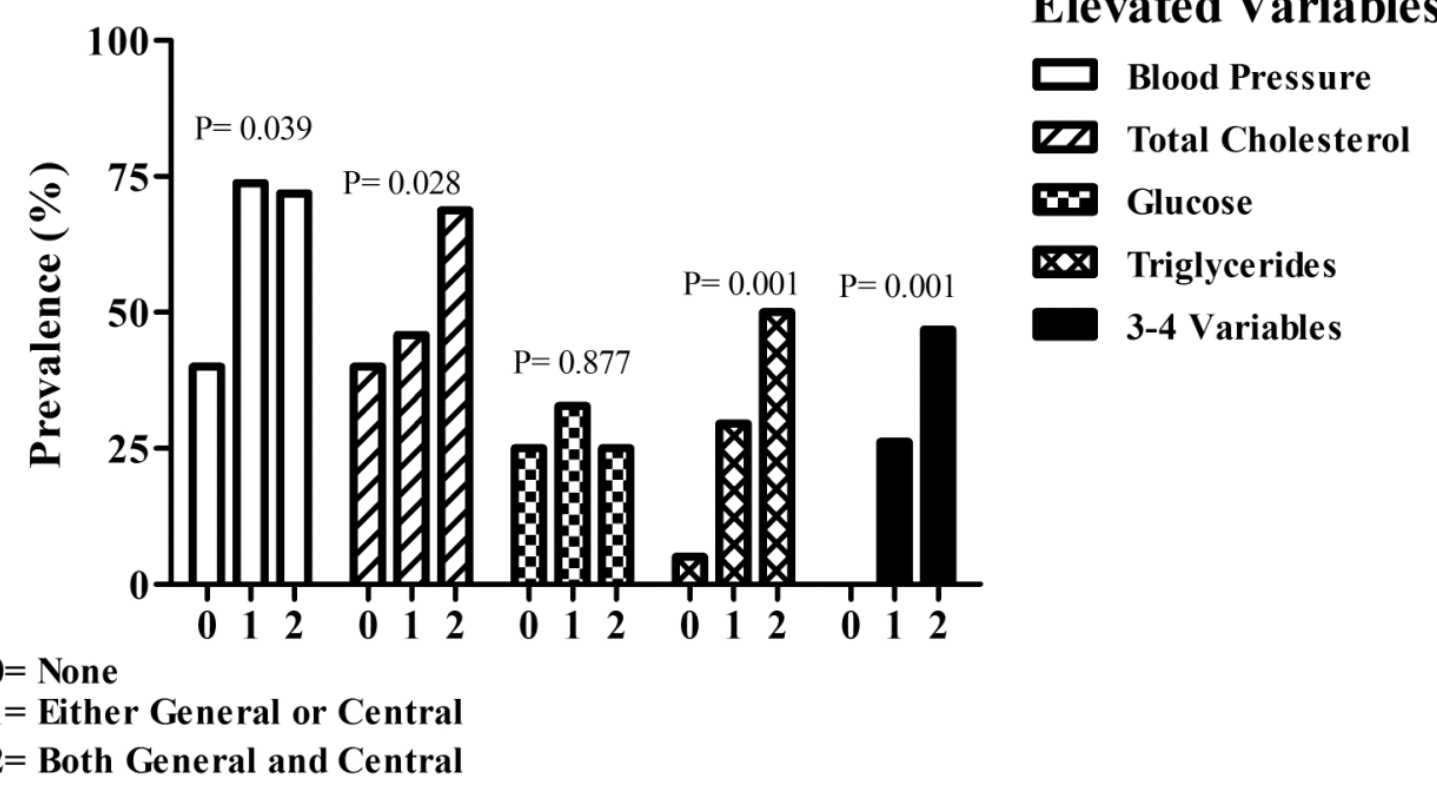

Figure 1: Presence of General and Central Obesity according CRFs

\section{Discussion}

Several studies have shown that the presence of certain risk factors in elderly subjects is related to a higher mortality rate ${ }^{18}$ and higher prevalence of multimorbidity ${ }^{19,20}$; however, few authors have investigated CRFs in subjects over 80 years of age. ${ }^{21}$

Risk factors are conditions that predispose individuals to an increased risk of developing heart disease ${ }^{22}$, among which are included hypertension, hypertriglyceridemia, hypercholesterolemia, hyperglycemia and an excess of total and abdominal body fat. ${ }^{23}$

Scientific evidence has reported that an unfavorable lipid profile in the elderly increases the risk of atherosclerosis, which, in turn, is an important risk factor for myocardial infarction. ${ }^{24}$ Regarding hypercholesterolemia, for example, data from North American individuals aged 65 years or over, revealed a prevalence of $60.3 \% .{ }^{25}$ In Brazil, the prevalence had a very similar value $(66.6 \%)$ in individuals of the same age ${ }^{26}$, however, this prevalence was lower in a recent study, conducted with individuals aged 80 or over $(51.3 \%){ }^{27}$

Despite the direct relationship between risk factors and mortality observed in almost all populations, in older seniors, such as in those aged 80 years or over, this relationship does not present the same association. Iversen et al, observed that the risk of incidences of coronary heart disease associated with hypercholesterolemia, decreases with age in a healthy population. ${ }^{21} \mathrm{~A}$ similar result was observed by Petersen et al, in subjects aged 80 or over, who reported that hypercholesterolemia was not associated with an increased risk of cardiovascular events and mortality. ${ }^{28}$

The accumulation of chylomicrons and/or VLDL-cholesterol in the plasma compartment results in hypertriglyceridemia. ${ }^{17}$ There is evidence that elevated triglyceride levels may be an independent risk factor for cardiovascular disease. ${ }^{29}$

In Brazil, there is high rate of hypertriglyceridemia in elderly patients. ${ }^{30}$ In the present study, those with excess total body fat presented higher TG and TC, and those with excess abdominal fat presented higher TC. These results corroborate the study by Peltola et al, since excess body fat (total and abdominal) was positively associated with elevated triglycerides levels ${ }^{31}$, as well as the study conducted recently in Brazil with individuals aged 60 or over, where it was observed that obese individuals presented higher triglycerides. ${ }^{30}$ 
Another risk factor is excess body fat, especially deposited in the abdominal region. ${ }^{23}$ In the present study, the individuals with a higher percentage of abdominal fat presented a higher prevalence of hypercholesterolemia ( $66.6 \%$ vs $44.1 \%$ ). These data are in agreement with the study of $\mathrm{Da}$ Cruz et al, where male subjects, aged 80 or over with excess abdominal fat, presented higher total cholesterol concentration than individuals with normal abdominal fat. 32

Similar results were observed in the study by Peltola et al, which examined middle-aged adults, of both sexes, and found a positive association between hypercholesterolemia and excess abdominal fat. ${ }^{31}$ Such relationships are expected, since abdominal fat is strongly related to high values of LDL-cholesterol and low values of HDL-cholesterol and is responsible for the excessive release of free fatty acids, cytokines and other pro-inflammatory products, which lead to atherosclerotic plaque formation and cardiovascular disease. ${ }^{7}$

The prevalence of hypertension in elderly individuals in this study, with the exception of the group without excess total body fat, presented values above those observed in patients aged 60 years or over from Latin American countries such as Cuba $(44.1 \%)$, Mexico (43.1\%), Uruguay (44.9\%), Chile $(52.3 \%)$ and Brazil (53.8\%). ${ }^{33}$ In studies with an exclusively Brazilian population it was observed that the prevalence increases with age. Such evidence has been observed in studies by Reichert et al, with individuals aged 40 years or over, where a prevalence of $34.4 \%$ of individuals with hypertension was identified. ${ }^{34}$

The study of Zaitune et al, with individuals aged 60 years or over, found a prevalence of $51.8 \%$ of hypertensive subjects ${ }^{35}$ and the study of Gomes et al, with individuals aged 80 years or over observed a prevalence of $67.3 \% .^{27}$

However, the prevalence of hypertension in elderly individuals with excess of body fat was higher in the present study. This finding is consistent with the study of Feijão et al with adults aged 30 years and over that found a strong association between hypertension and overweight ( $O R=1.59)$, and obesity $(\mathrm{OR}=2.4) .{ }^{36}$ The association between body fat and hypertension is still not fully understood, although some evidence can be considered.
Hall et al, indicated that an increase in blood pressure caused by excess body fat occurs due to a decrease in natriuresis. ${ }^{37}$ With increasing age, chronic hypertension causes damage in arterial walls, which hinders blood flow and therefore increases blood pressure; this could have occurred in the sample of the present study. Evidence of this effect was also found in the literature. ${ }^{25}$

The current study presents important evidence with respect to the profile of some CRFs affecting the investigated subjects. In terms of public health, these findings can be applied in some areas of the health services, such as: protection against CRFs, better distribution of income for these services and preparation of health professionals who will take care of the increasingly elderly population.

Besides this important evidence, some limitations must be reported. The results are from a sample of only one Brazilian geographical location. The cross-sectional design did not permit establishment of the causality relationship between the CRFs and total and abdominal body fat. The high non-participation rate should be underscored as a major limitation of this study; however a possible cause of this is the difficulty the elderly have in travelling around.

In addition, analyzes were performed without considering the level of physical activity as a confounding variable. It is possible that older adults with higher levels of physical activity would present lower prevalences of hypertension and better control of the blood variables studied.

\section{Conclusion}

We concluded that arterial hypertension is directly associated with the presence of excess weight and not with abdominal obesity in people over 80 years of age. On the other hand, regardless of the pattern of fat distribution, individuals aged 80 years or over, with excessive total and abdominal fat presented higher values of hyperlipidemia, and, consequently, high cardiovascular risk factors.

\section{Competing Interests}

The authors declare that there are no competing interests with respect to the authorship and/ or publication of this article. 


\section{Funding}

The authors received no financial support for the research and/or authorship of this article.

\section{References}

1. Carvalho JAM, Rodriguez-Wong LL. The changing age distribution of the Brazilian population in the first half of the 21 st century. Cad Saúde Pública. 2008; 24:597-605.

2. Duncan BB, Chor D, Aquino EML, Bensenor IM, Mill JG, Schmidt MI, et al. Doenças crônicas não transmissíveis no Brasil: prioridade para enfrentamento e investigação. Rev Saúde Pública. 2012; 46:126-34.

3. Abete I, Goyenechea E, Zulet MA, Martínez JA. Obesity and metabolic syndrome: Potential benefit from specific nutritional components. Nutr Metab Cardiovasc Dis. 2011; 21(Suppl 2):B1-15

4. Bastien M, Poirier P, Lemieux I, Després JP. Overview of epidemiology and contribution of obesity to cardiovascular disease. Prog Cardiovasc Dis. 2014; 56:369-81.

5. Kohara K. Sarcopenic obesity in aging population: current status and future directions for research. Endocrine. 2014; 45:15-25.

6. Karine C, Spiegelman BM, Christen Y. Novel insights into adipose cell functions. In: Pathological alteration of human adipose tissue in obesity. Springer, London; 2010:1-13.

7. Cao H. Adipocytokines in obesity and metabolic disease. $J$ Endocrinol. 2014; 220:T47-T59.

8. Ibrahim MM. Subcutaneous and visceral adipose tissue: structural and functional differences. Obes Rev. 2010; 11:11-18

9. Di Bonito P, Valerio G, Grugni G, Licenziati MR, Maffeis C, Manco M, et al. Comparison of non-HDL-cholesterol versus triglycerides-to-HDL-cholesterol ratio in relation to cardiometabolic risk factors and preclinical organ damage in overweight/obese children: The CARITALY study. Nutr Metab Cardiovasc Dis. 2015; 25: 489-94.

10. Albala C, Lebrão ML, León Díaz EM, Ham-Chande R, Hennis AJ, Palloni A, et al. The Health, Well-Being, and Aging ("SABE") survey: methodology applied and profile of the study population. Rev Panam Salud Publica. 2005; 17:307-22.

11. Lohman TG, Roche AF, Martorell R: Anthropometric standardization reference manual. Champaign. IL, Human Kinetics Books; 1988

12. Morrow JR, Jackson AW, Disch JG, Mood DP. (2003). Medida e avaliação do desempenho humano. $2^{2}$ ed. Artmed, Porto Alegre.

13. Pickering TG, Hall JE, Appel LJ, Falkner BE, Graves J, Hill $\mathrm{MN}$, et al. Subcommittee of Professional and Public Education of the American Heart Association Council on High Blood Pressure Research. Recommendations for blood pressure measurement in humans and experimental animals: Part 1: blood pressure measurement in humans: a statement for professionals from the Subcommittee of Professional and Public Education of the American Heart Association Council on High Blood Pressure Research. Hypertension. 2005; 45:14261

14. Coleman A, Freeman P, Steel S, Shennan A. Validation of the Omron MX3 Plus oscillometric blood pressure monitoring device according to the European Society of Hypertension international protocol. Blood Press Monit. 2005; 10:165-8.
15. Chobanian AV, Bakris AV, Black HR, Cushman WC, Green LA, Izzo JLJ, et al., Seventh report of the joint national committee on prevention, detection, evaluation, and treatment of high blood pressure. JAMA. 2003; 42:1206-52.

16. Human RP, Jones GA. Evaluation of swab transport systems against a published standard. J Clin Pathol. 2004; 57:76273.

17. Department of Atherosclerosis of the Brazilian Society of Cardiology. IV Diretriz Brasileira sobre Dislipidemias e Prevenção da Aterosclerose. Departamento de Aterosclerose da Sociedade Brasileira de Cardiologia. Arq Bras Cardiol. 2007; 88: 2-19.

18. Werle MH, Moriguchi E, Fuchs SC, Bruscato NM, Carli W, Fuchs FD. Risk factors for cardiovascular disease in the very elderly: results of a cohort study in a city in Southern Brazil. EurJ Cardiovasc Prev Rehabil. 2011; 18: 369-77.

19. Rocca WA, Boyd CM, Grossardt BR, Bobo WV, Rutten LJF, Roger VL, et al. Prevalence of multimorbidity in a Geographically defined American population: Patterns by age, sex, and race/ethinicity. Mayo Clin Proc. 2014; 89:1336-49.

20. Violan C, Foguet-Boreu Q, Flores-Mateo G, Salisbury C, Blom $\mathrm{J}$, Freitag M. Prevalence, determinants and patterns of multimorbidity in primary care: A systematic review of observational studies. PLos ONE. 2014; 9: e102149.

21. Iversen A, Jensen JS, Scharling H, Schnohr P. Hypercholesterolemia and risk of coronary heart disease in the elderly: Impact of age: The Copenhagen city heart study. Eur J Intern Med. 2009; 20:139-44.

22. Mozaffarian D, Benjamin EJ, Go AS, Arnett DK, Blaha MJ, Cushman M, et al. Executive summary: heart disease and stroke statistics-2015 update: a report from the American Heart Association. Circulation. 2015;131:434-41.

23. Diniz MA, Tavares DMS. Fatores de risco para doenças cardiovasculares em idosos de um município do interior de Minas Gerais. Texto Contex. Enferm 2013; 22:885-892.

24. Wang SK, Ma W, Wang S, Yi XR, Jia HY, Xue F. Obesity and its relationship with hypertension among adults 50 years and older in Jinan, China. PLos ONE. 2014; 9:e114424.

25. McDonald M, Hertz RP, Unger AN, Lustik MB. Prevalence, awareness, and management of hypertension, dyslipidemia, and diabetes among United States adults aged 65 and older. J Gerontol A Biol Sci Med Sci 2009; 64A:256-63.

26. Rigo JC, Vieira JL, Dalacorte RR, Reichert CL. Prevalence of metabolic syndrome in an elderly community: Comparison between three diagnostic methods. Arq Bras Cardiol. 2009; 93:80-6.

27. Gomes IC, Santos VR, Christofaro DGD, Santos LL, FreitasJr IF. The most frequent cardiovascular risk factors in Brazilian aged 80 years or older. J Appl Gerontol. 2013; 32: 40821.

28. Petersen LK, Christensen K, Kragstrup J. Lipid-lowering treatment to the end? A review of observational studies and RCTs on cholesterol and mortality in 80+year olds. Age Ageing. 2010; 39:674-80.

29. Miller M, Stone NJ, Ballantyne C, Bittner V, Criqui MH, Ginsberg $\mathrm{HN}$, et al. Triglycerides and cardiovascular disease: a scientific statement from the American Heart Association. Circulation. 2011;123:2292-333.

30. Scherer F, Vieira JLC. Estado nutricional e sua associação com risco cardiovascular e síndrome metabólica em idosos. Rev Nutr. 2007; 23:347-55. 
31. Peltola P, Pihlajamaki J, Koutnikova H, Ruotsalainen E, Salmenniemi U, Vauhkonen I, et al. Visceral obesity is associated with high levels of serum squalene. Obesity (Silver Spring). 2006; 14:1155-63.

32. Da Cruz IBM, Almeida MSC, Schwanke CHA, Moriguchi EH. Obesity prevalence among oldest-old and its association with risk factors and cardiovascular morbidity. Rev Assoc Med Bras. 2004; 50:172-7.

33. Menendez J, Guevara A, Arcia N, Diaz EML, Marin C, Alfonso JC. Chronic diseases and functional limitation in older adults: A comparative study in seven cities of Latin America and the Caribbean. Rev Panam Salud Publica. 2005; 17:353-61.

34. Reichert FF, Azevedo MR, Breier A, Gerage AM. Physical activity and prevalence of hypertension in a population-based sample of Brazilian adults and elderly. Prev Med. 2009; 49:200-4.
35. Zaitune MPA, Barros MBA, César CLG, Carandina L, Goldbaum M. Arterial hypertension in the elderly: prevalence, associated factors, and control practices in Campinas, São Paulo, Brazil. Cad Saúde Pública. 2006; 22: 285-94.

36. Feijão AMM, Gadelha FV, Bezerra AA, Oliveira AM, Silva MSS, Lima JW. Prevalence of excessive weight and hypertension in a low-income urban population. Arq Bras Cardiol. 2005; 84:29-33.

37. Hall JE, Zappe D, Galicia AM, Kassab S. Mechanisms of obesity induced Hypertension. Physiol. 1996; 11:255-61. 